SB 359
B26
Copy 1

SB 359
. B26
Copy 1

SB 359
. B26
Copy 1

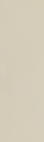

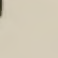

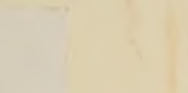

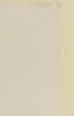

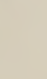


LIBRARY OF CONGRESS

. IIIII

00214892200 


\section{KANSAS \\ AS A FRUIT STATE.}

In 1850 Kansas was practically treeless. Along the larger streams, where a rocky bluff bordered the south or west side as a protection from prairie fires, across the stream from the bluff, generally a rich bottom, contained a growth of timber. As the country became settled and farms were opened the prairie fires were checked, and these timber belts have widened out, so that there are thousands of acres of natural forest in Kansas now where there were only hundreds in 1860. Our citizens have not only encouraged this extension, but have planted thousands of acres in addition. The belief in the late ' 50 's and early ' 60 's was general, that these treeless plains were not naturally adapted to tree growth, especially fruit-tree growth, and when a few adventurous parties planted orchards they met little encouragement in the dire prophecies of loss and disaster of their incredulous neighbors.

But there were wild strawberries all along the Santa Fe trail, blackberries and raspberries of fine quality in the timber openings and along the bayous and ravines, wild grapes climbed the 
trees, wild cherries were common, and wild plums of many varieties grew in great abundance. over many miles of the territory. Why should not fruit do well here under cultivation?

Those who early tried found they had reckoned well; the newly planted trees grew vigorously, showing perfect health and that the soil suited them, and, to the surprise of the planters, they bore fruit while very young; some the third year from setting, a thing never heard of in the East. Trees in nursery rows only two years of age have produced good apples in Kansas. So early and so vigorously did fruit-trees grow and bear fruit, that wonderful stories were circulated about walking-sticks stuck in the soil and fence stakes driven in place which fruited two years after: that grape and pear cuttings could be thrust into the virgin soil almost anywhere and would soon produce fruit.

Those stories attracted the attention of many. unscrupulous nurserymen with surplus and overgrown nursery stock in states farther east, and from 1869 to 1875 car-load after car-load of misnamed, stunted, irregular and degenerate fruittrees were unloaded on the settlers, at top prices and in immense quantities. No farmer thought he had a home until he had an orchard. Those tree merchants were so clever, so accommodating, so very wise, and they gave away freely so much advice which would surely (?) lead to success, that willingly they were paid their exorbitant prices, their labels were considered scripture-true, and they parted company with a "God bless you" 
to the planter and compliments to his bright, attractive wife. A very few years after, when the little, knotty seedlings or abandoned and neveruseful varieties came to bear a few scattering specimens, these same planters would have liked a few minutes' earnest conversation with the renegade who sold them the trees.

During this era when the wonderful success of a few caused exaggerated ideas to prevail, that any old thing would produce fruit if planted in Kansas soil, millions of trees were set out that were only a disappointment and a delusion - they have since become only a memory; but such lack of success discouraged many.

During this period, in 1869, the Kansas State Horticultural Society began its work. A few citizens with the true missionary spirit of making the world better organized it; and its work up to the present time has been worth untold millions to the state. Its members have labored incessantly along all experimental lines, using their own money, labor and talents to develop the best means and to discover the best varieties, and to study out how to plant, cultivate, prune, pick, pack, store and market all fruits adapted to this climate, and to give this information free to all inquirers. No fruit-growers are more energetic, intelligent, industrious and beneficial to their state than those belonging to the Kansas State Horticultural Society; as a result, the largest apple orchards in the world are in Kansas.

Judge Fred. Wellhouse, of Topeka, has 1636 acres; and, at the age of seventy-four, with all 
the enthusiasm of youth he is growing the youngr trees to plant 120 acres more. He once filled twenty-two cars, all going in one train, with Kansas Ben Davis apples of finest quality, for one man, who took them to New York city.

In the last twelve years Judge Wellhouse has grown in Kansas nearly one-half million bushels: of apples, for which he received an average of twenty-eight cents per bushel. He has increased his orchards until now he has more than 1600 acres: in Leavenworth, Miami and Osage counties.

When the seasons are as favorable as the season of 1902 , he raises from 60,000 to 80,000 bushel's. In hot and dry seasons his yield falls as low as: 400 bushels. In the season of 1893 he did not pick the crop at all.

The judge's original venture in apple raising: was on a 120-acre tract, planted in 1876 near Leavenworth. The land was poor in quality, so far as the production of wheat or corn was concerned, and many looked upon his venture with doubt. It was successful. In 1878 he planted another quarter-section; in 1879 he planted an additional quarter, and increased his plantings as. follows: In 1889 he planted 250 acres in Leavenworth county ; in 1890,540 acres in Osage county ; in 1894, another 270-acre tract in Leavenworth county, and in 1896, another 140 acres in the same section.

The leading varieties are as follows : Ben Davis, 620 acres; Winesap, 76 acres ; Missouri Pippin, 409 acres ; Jonathan, 190 acres ; York Imperial, 
150 acres ; Gano, 160 acres ; Maiden's Blush, 16 acres ; Cooper's Early, 16 acres.

The yield of fruit by years has been as follows: 1830, 1594 bushels; 1881, 3887 bushels; 1882, 12,097 bushels ; $1883,12,338$ bushels ; 1884 , 11,726 bushels ; 1885, 15,373 bushels ; $1886,34,909$ bushels ; 1887, 33,790 bushels ; $1888,20,054$ bushels ; 1889, 14,307 bushels ; 1890, 79,170 bushels ; 1891, 63,689 bushels; 1892, 793 bushels; 1893, no harvest, crop being ruined by hail-storms; $1894,47,374$ bushels ; $1895,59,138$ bushels ; 1896 , 784 bushels ; 1897,3758 bushels ; 1898, 3639 bushels; 1899, 488 bushels; 1900, 88,940 bushels; 1901, 33,464 bushels.

This year he expects to harvest a crop of 60,000 or 70,000 bushels. Although there have been some total failures recorded, the apple business has paid.

In the years when he picked 80,000 bushels or more, Mr. Wellhouse's expenses were nearly $\$ 15$,000 annually; his receipts for 1890 were $\$ 52,000$. In his years of apple raising he has realized a net profit of $\$ 104,000$, not considering the increased value of his holdings in Kansas land.

Mr. Wellhouse has found the Ben Davis apple to be the most profitable, while the Jonathan has yielded the most bushels to the acre. Missouri Pippin comes second in yield and Ben Davis third. On Fairmount Hill, near Leavenworth, he has erected a large packing plant, and another at Tonganoxie, and his shipments of fruit are made to Kansas City, Chicago, New York, Boston, and other points. 
There are many large orchards, and many of our growers have this year from 5000 to 10,000 bushels of apples. Our state ranks fifth in number $(12,000,000)$ of apple trees in bearing, Missouri, New York, Illinois and Ohio only being ahead of us. We will soon be second only to Missouri. Kansas apples, especially Ben Davis, Missouri Pippin, and Jonathan, are said by specialists from Washington, D. C., to be the best in the world.

In the whole Union, only thirty counties contain over 400,000 apple trees ; two of these counties, viz., Doniphan and Leavenworth, are in Kansas. In Kansas, apples grow on upland or lowland, rolling land or level plain, and our people are putting out between one and two million trees per year.

Pears do elegantly and bear abundantly, of most luscious quality. We have pear blight, but no more than the other states.

Our state is the home of the peach, and abundant crops are grown in nearly all parts of it. Many car-loads are annually shipped out to Northern and Eastern points.

Plums of the most-approved varieties grow readily in every county, and wild plums along the Arkansas river, by the hundreds of acres, are a sight worth coming a long distance to look upon. Thousands of bushels of plums waste each year for want of a market.

Cherries are a sure crop, and often bring $\$ 250$ an acre to the grower. 
Mulberries, nectarines, apricots, persimmons, all grow and bear well.

Grapes, from Delaware to Concord, with all between-even so-called California varieties - are easily grown and are always plentiful. Our people raise them for the table and do not abuse this great blessing by any process of ferment, decay or rot in order to make an intoxicant, under whose influence they may insult and blaspheme Him to whom we owe this luscious, health-giving fruit. If God had the passions of man, no grapevine whose fruit was made into an intoxicant would survive. Kansans-men, women, and children-eat grapes in abundance.

Kansas is the home of the berry; no finer strawberries, raspberries or blackberries are grown in quantity anywhere; and several of the bestpaying varieties originated here. Strawberries often yield over 300 bushels per acre.

Vegetables of every kind found in the market grow luxuriantly in Kansas.

Watermelons weighing sixty to seventy-five and even ninety pounds are shown at our fairs, and their quality is of the very best. Muskmelons equaling the famous Rocky Fords are plentiful everywhere. Many a farmer boy drops a few melon seeds in the midst of a big corn-field and regales himself and his fellows off of the products.

Celery of equal quality, and several times larger than that from Kalamazoo, Mich., is readily grown in Kansas.

Eggplant, asparagus and all the commoner 
vegetables are as common in Kansas homes as anywhere.

If you want all the good things that will grow out of earth in the temperate zone, and want them in season and out of season on your tables; if you want your boys and girls to have vigorous bodies and clear, quick, snappy brains; if you want to make the world better and its future population of a higher grade; if you want to live happy and spend your declining years in serene, calm enjoyment, and then make the shortest cut to the happy hereafter, you should at once gather your shekels and your progeny and hale to Kansas, and get a little, or big, patch of her beautiful, bountiful soil, and mix with her wonderful people.

\section{WILLIAM H. BARNES,}

Secretary State Horticultural Society, TOPEKa, KaN. 

LIBRARY OF CONGRESS

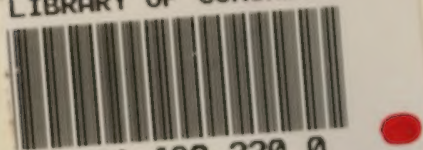

00214892200 